\title{
The role of thymine starvation in the expression of type IV plasmid-encoded trimethoprim-resistant dihydrofolate reductase
}

\author{
C. J. THOMSON, HILARY-KAY YOUNG* and S. G. B. AMYES
}

Department of Medical Microbiology, The Medical School, University of Edinburgh, Teviot Place, Edinburgh EH8 9AG and "Department of Biological Sciences, University of Dundee, Dundee DD1 4HN

\begin{abstract}
Summary. Hyperproduction of the type IV plasmid-encoded dihydrofolate reductase was studied in Escherichia coli J62-2 (pUK1123). Hyperproduction of the enzyme was shown to occur not simply as a response to a given concentration of trimethoprim but also to the presence of thymidine in the medium. Before hyperproduction occurred the bacteria began to elongate and die, thus showing the symptoms of thymine starvation. Hyperproduction also required the presence of L-methionine, adenine and glycine, suggesting that the elevated production of the enzyme was a response to the ability of trimethoprim to starve the cell of thymine metabolites.
\end{abstract}

\section{Introduction}

Trimethoprim selectively inhibits bacterial dihydrofolate reductase $\left(5,6,7,8\right.$-tetrahydrofolate: $\mathrm{NADP}^{+}$ oxidoreductase EC 1.5.1.3) which catalyses the reduction of dihydrofolate to tetrahydrofolate. This deprives the cell of an essential co-factor for the biosynthesis of purines, pyrimidines and amino acids. ${ }^{1}$ Several mechanisms of resistance to trimethoprim have been reported, the most common being the plasmid-encoded production of an additional trimethoprim-resistant dihydrofolate reductase that enables the trimethoprim blockade of the chromosomal enzyme to be by-passed. ${ }^{2}$ To date, 14 plasmidmediated dihydrofolate reductases have been identified from sequence and biochemical data..$^{3-5}$ Of these, the type IV enzyme is unique, as it is the only plasmidmediated dihydrofolate reductase for which the specific activity of the enzyme is dependent on the concentration of trimethoprim. ${ }^{6}$ Although hyperproduction of the Escherichia coli chromosomal dihydrofolate reductase is well documented as a resistance mechanism, ${ }^{7,8}$ this has been shown only once to be the result of induction rather than constitutive high-level production. ${ }^{9}$

The type IV dihydrofolate reductase, which was identified in strains isolated in South India in 1984, confers only partial trimethoprim resistance. ${ }^{10}$ The MIC of trimethoprim for the host strain is dependent on the test medium and resistance is only moderate even in optimum conditions, despite the high levels of dihydrofolate reductase that can be achieved. ${ }^{10}$
In this study we examined the physiological response of $E$. coli harbouring a plasmid producing type IV dihydrofolate reductase and considered the role of dihydrofolate reductase production in trimethoprim resistance.

\section{Materials and methods}

\section{Bacterial strains and plasmids}

All experiments were performed with $E$. coli strain J62-2 (pUK1123), an E. coli transconjugant containing the original plasmid isolated from a clinical strain in $1984 .^{6}$

\section{Culture media}

The complex medium used for exposure to trimethoprim was IsoSensitest Broth (Oxoid); the solid medium used was Diagnostic Sensitivity Test Agar (DSTA; Oxoid). These media were chosen because neither contain significant amounts of thymine derivatives that would affect the action of trimethoprim. ${ }^{11}$ Thymidine (Sigma) and trimethoprim (Wellcome Research Foundation, Crewe) were added as required. Davis-Mingioli medium ${ }^{12}$ supplemented with glucose, L-proline, L-histidine, L-tryptophan, L-methionine, adenine and glycine, as required, was used as the minimal medium. 
cultures of bacteria grown with vigorous agitation at $37^{\circ} \mathrm{C}$ in the appropriate medium. The cells were harvested by centrifugation $(6000 \mathrm{~g}$ for $10 \mathrm{~min}$ at $15^{\circ} \mathrm{C}$ ) and resuspended in buffer A (50 mM sodium phosphate, $\mathrm{pH} 7 \cdot 4$, containing $10 \mathrm{~mm} \beta$-mercaptoethanol and $1 \mathrm{~mm}$ EDTA). The bacteria were disrupted by sonication and the cell debris was removed by centrifugation $\left(40000 \mathrm{~g}\right.$ for $60 \mathrm{~min}$ at $4^{\circ} \mathrm{C}$ ). Dihydrofolate reductase activity was assayed at $37^{\circ} \mathrm{C}$ in $40 \mathrm{~mm}$ sodium phosphate buffer, $\mathrm{pH} \mathrm{6,} \mathrm{as} \mathrm{described} \mathrm{pre-}$ viously. ${ }^{2}$ One unit of dihydrofolate reductase activity was defined as the amount of enzyme required to reduce $1 \mathrm{nmol}$ of dihydrofolate $/ \mathrm{min}$. The specific activity was determined by measuring the protein concentration in each cleared lysate by the method of Waddell. ${ }^{13}$

Effect of trimethoprim and thymidine on dihydrofolate reductase expression

A series of cultures of $E$. coli J62-2 (pUK1123) in $250 \mathrm{ml}$ of IsoSensitest broth was challenged with increasing concentrations of trimethoprim or with trimethoprim $40 \mathrm{mg} / \mathrm{L}$ and increasing concentrations of thymidine $(0-50 \mathrm{mg} / \mathrm{L})$. The cells were harvested after $20 \mathrm{~h}$ at $37^{\circ} \mathrm{C}$ and disrupted by sonication. The specific activity of dihydrofolate reductase was measured as described above.

\section{Effect of trimethoprim on viable count and cell morphology}

E. coli J62-2 (pUK1123) was inoculated directly from a DSTA plate into two flasks containing $250 \mathrm{ml}$ of IsoSensitest broth, with and without trimethoprim $40 \mathrm{mg} / \mathrm{L}$. The flasks were incubated at $37^{\circ} \mathrm{C}$ and shaken vigorously for $24 \mathrm{~h}$. At time 0 and every $4 \mathrm{~h}$ thereafter, a viable count and Gram's stain was performed on the bacteria in each flask. In a separate experiment, cultures were exposed to trimethoprim $40 \mathrm{mg} / \mathrm{L}$ in the presence and absence of thymidine $2 \mathrm{mg} / \mathrm{L}$ and examined over a $24-\mathrm{h}$ period in a similar way.

The role of L-methionine, glycine and adenine on enzyme expression

E. coli J62-2 (pUK1123) was challenged in DavisMingioli minimal medium supplemented with glucose $2.8 \mathrm{mg} / \mathrm{L}$ and the auxotrophic requirements for this strain (L-proline, L-histidine and L-tryptophan, each at $50 \mathrm{mg} / \mathrm{L}$ ). Different combinations of L-methionine, adenine and glycine $(50 \mathrm{mg} / \mathrm{L}$ of each) were also added. The effects of challenge with trimethoprim were monitored as before, but 1-L cultures were used to compensate for the slower growth rates and the lower bacterial yield in minimal medium.
Table I. Production of the type IV dihydrofolate reductase in $E$. coli $\mathrm{J} 62-2$ (pUK1123) as a function of trimethoprim concentration

\begin{tabular}{cc}
\hline $\begin{array}{c}\text { Trimethoprim concentration } \\
(\mathrm{mg} / \mathrm{L})\end{array}$ & $\begin{array}{c}\text { Enzyme specific } \\
\text { activity* }\end{array}$ \\
\hline 0 & $3 \cdot 7$ \\
10 & $49 \cdot 7$ \\
20 & $50 \cdot 2$ \\
40 & $52 \cdot 8$ \\
80 & $121 \cdot 5$ \\
160 & $625 \cdot 0$ \\
\hline
\end{tabular}

* nmol of dihydrofolate reduced $/ \mathrm{min} / \mathrm{mg}$ of protein.

Table II. Production of the type IV dihydrofolate reductase in $E$. coli J62-2 (pUK1123) after exposure to trimethoprim $40 \mathrm{mg} / \mathrm{L}$

\begin{tabular}{cc}
\hline $\begin{array}{c}\text { Period of exposure } \\
\text { (h) }\end{array}$ & $\begin{array}{c}\text { Enzyme specific } \\
\text { activity* }\end{array}$ \\
\hline Control & $5 \cdot 7$ \\
2 & $2 \cdot 6$ \\
3 & $7 \cdot 6$ \\
5 & $3 \cdot 9$ \\
14 & $24 \cdot 6$ \\
18 & $23 \cdot 9$ \\
\hline
\end{tabular}

* See table I.

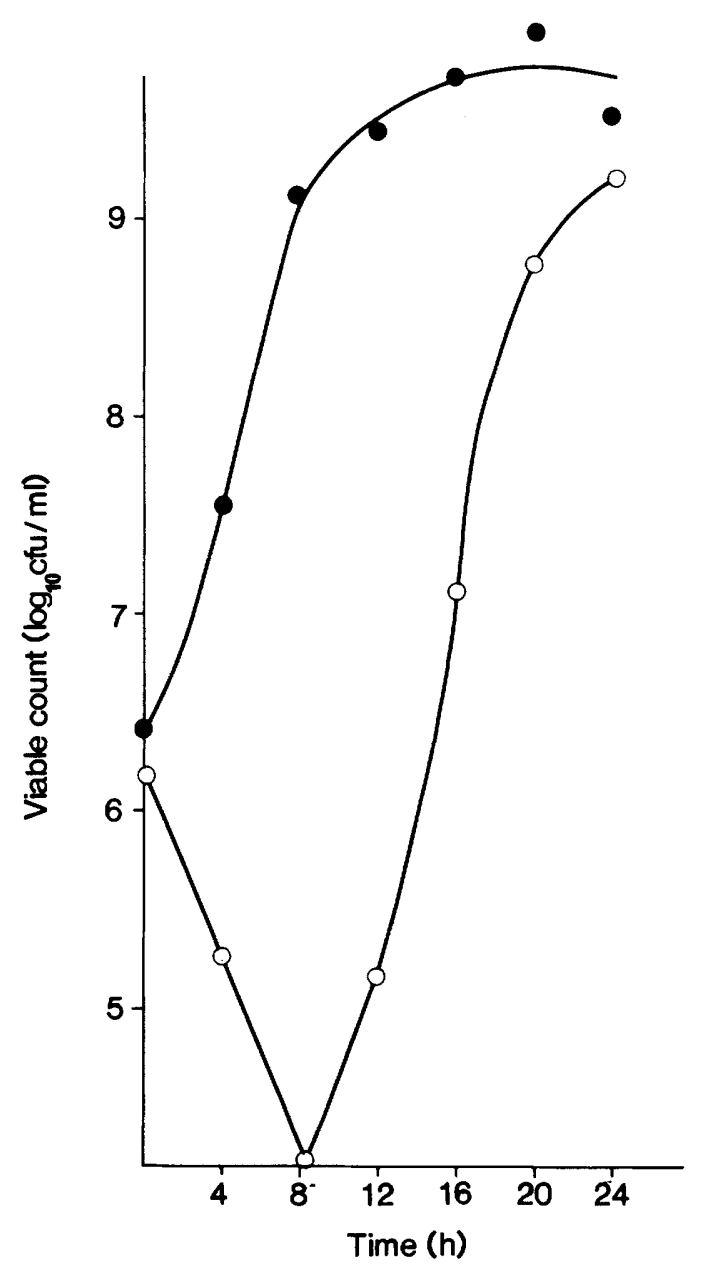

Fig. 1. Viable count of E. coli J62-2 (pUK1123) over $24 \mathrm{~h}$ in the presence $(O)$ and absence $(O)$ of trimethoprim $40 \mathrm{mg} / \mathrm{L}$. 


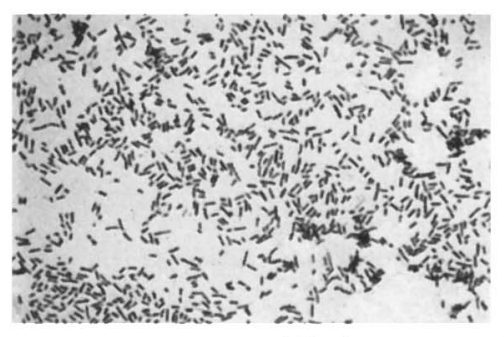

Time (h)
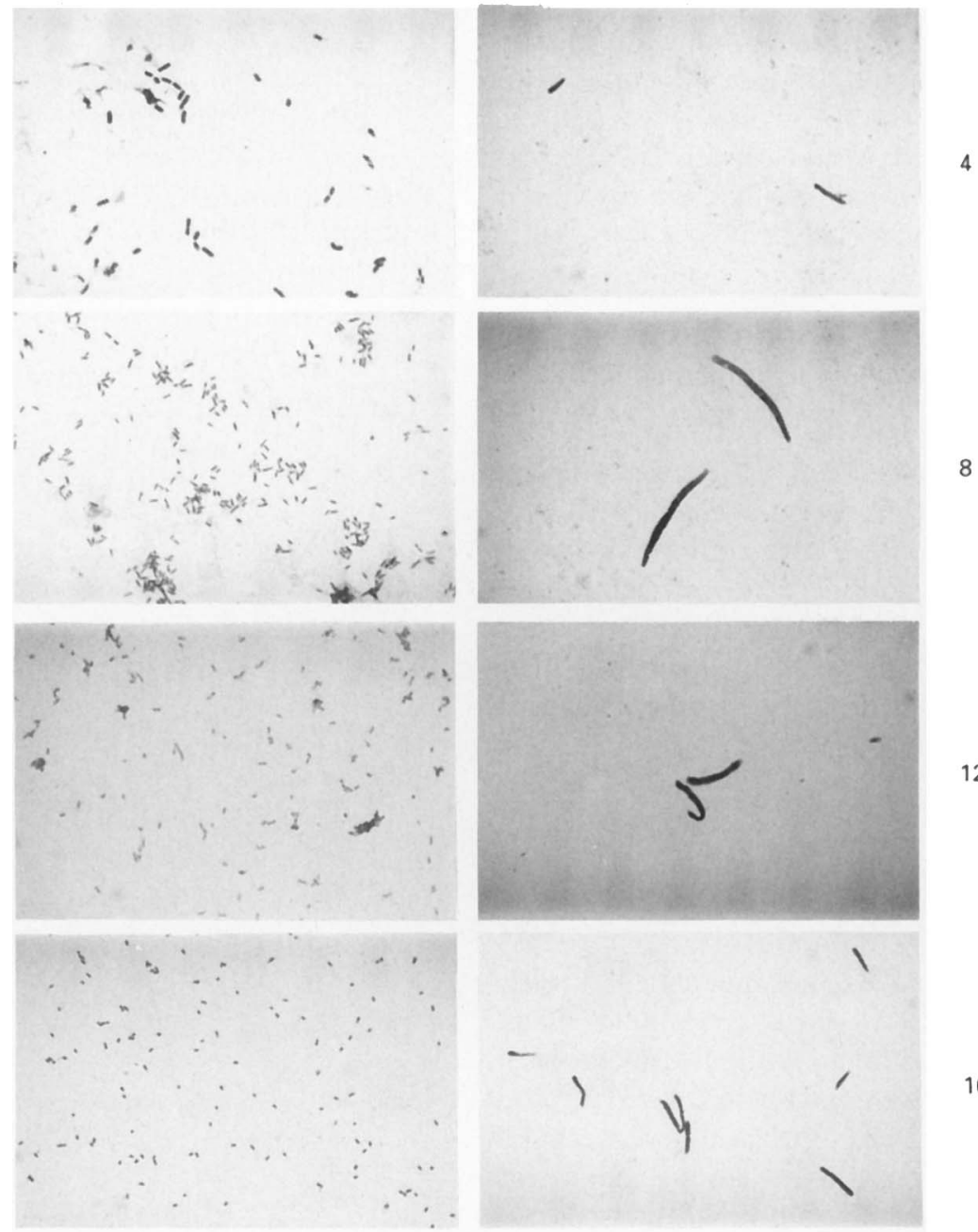

12

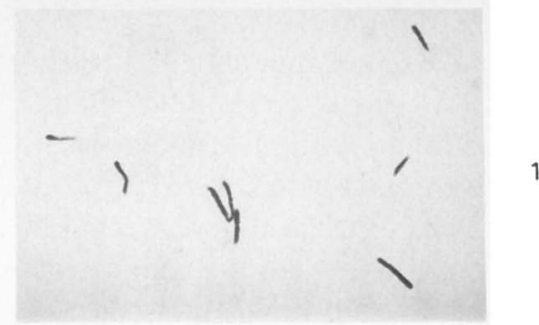

16
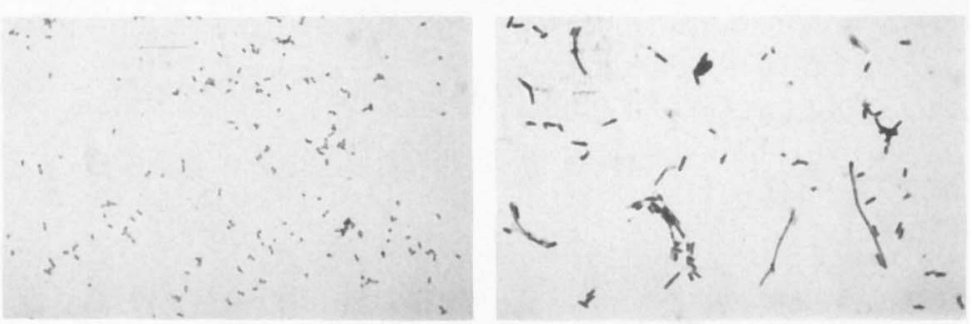

20

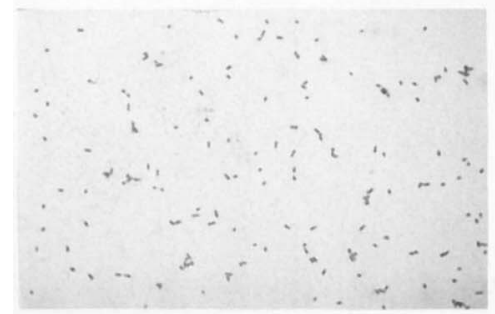

$\mathrm{Tp} 0 \mathrm{mg} / \mathrm{L}$

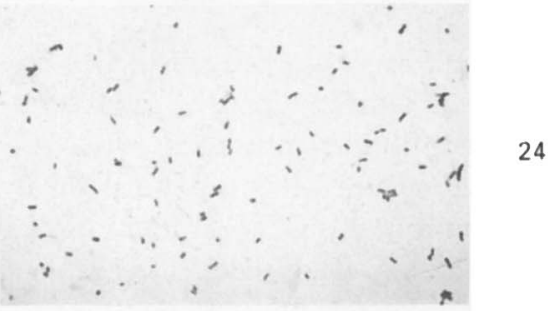

Tp $40 \mathrm{mg} / \mathrm{L}$

Fig. 2. Smears of E. coli J62-2 (pUK1123) grown over $24 \mathrm{~h}$ in the presence and absence of trimethoprim (Gram's stain). Magnification $\times 1250$. 


\section{Results and discussion}

\section{Expression of dihydrofolate reductase}

The highest concentration of trimethoprim that promoted high levels of dihydrofolate reductase production in $E$. coli J62-2 (pUK1123) without diminishing the final recovery of bacteria was $40 \mathrm{mg} / \mathrm{L}$ (table I). Challenge with trimethoprim 80 or $160 \mathrm{mg} / \mathrm{L}$ gave higher specific activities but the final cell counts were considerably reduced. For this reason the concentration of trimethoprim used in subsequent experiments was $40 \mathrm{mg} / \mathrm{L}$. Induction of high levels of the chromosomal dihydrofolate reductase sufficient to produce trimethoprim resistance in regulatory mutant strains of $E$. coli occurs within 3 min of exposure to trimethoprim. ${ }^{7}$ In contrast, when $E$. coli J62-2 (pUK1123) was challenged with trimethoprim $40 \mathrm{mg} / \mathrm{L}$, elevated levels of dihydrofolate reductase could not be detected for 5-14 h (table II). Although it was unclear what changes were taking place in the bacteria during this lag period, it was assumed that no growth could occur, since elevated levels of dihydrofolate reductase were not synthesised.

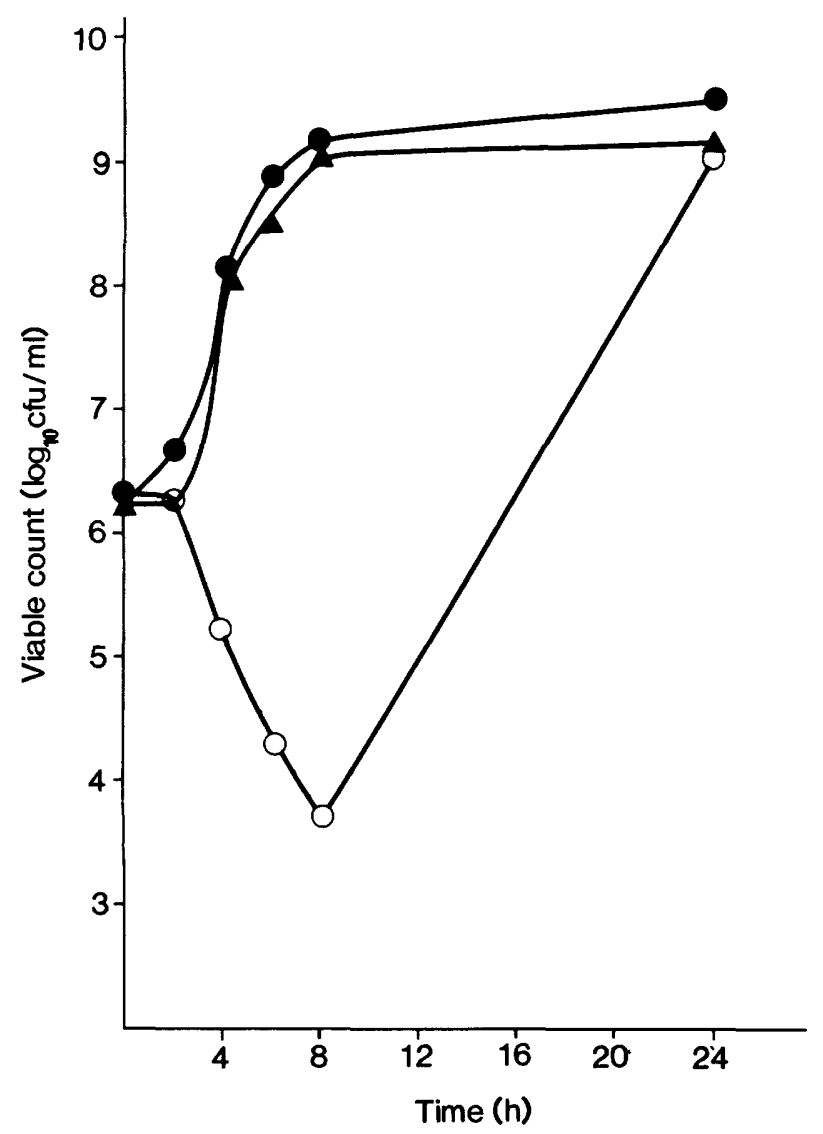

Fig. 3. Viable count of E. coli J62-2 (pUK1123) over $24 \mathrm{~h}$ in IsoSensitest broth containing no additions (O), trimethoprim $40 \mathrm{mg} / \mathrm{L}(\mathrm{O})$ or trimethoprim $40 \mathrm{mg} / \mathrm{L}$ and thymidine $2 \mathrm{mg} / \mathrm{L}(\boldsymbol{A})$.
Table III. The effect of thymidine on hyperproduction of the type IV dihydrofolate reductase in E. coli J62-2 (pUK1123) in the presence of trimethoprim $40 \mathrm{mg} / \mathrm{L}$.

\begin{tabular}{cc}
\hline $\begin{array}{c}\text { Concentration of thymidine } \\
(\mathrm{mg} / \mathrm{L})\end{array}$ & $\begin{array}{c}\text { Enzyme specific } \\
\text { activity* }\end{array}$ \\
\hline 0 & $33 \cdot 9$ \\
$0 \cdot 02$ & $33 \cdot 2$ \\
$0 \cdot 2$ & $17 \cdot 1$ \\
2 & $2 \cdot 3$ \\
10 & $2 \cdot 1$ \\
20 & $1 \cdot 3$ \\
50 & $1 \cdot 3$ \\
\hline
\end{tabular}

* See table I.

Table IV. The effect of L-methionine (met) adenine (ad) and glycine (gly) on production of the type IV dihydrofolate reductase in E. coli $\mathrm{J} 62-2$ (pUK1123) in minimal media

\begin{tabular}{lccc}
\hline Supplements* & $\begin{array}{c}\text { Trimethoprim } \\
\text { concentration } \\
(\mathrm{mg} / \mathrm{L})\end{array}$ & $\begin{array}{c}\text { Enzyme specific } \\
\text { activity }\end{array}$ & Growth \\
\hline None & 0 & $2 \cdot 5$ & +++ \\
None & 40 & $5 \cdot 9$ & +++ \\
met ad - & 0 & $2 \cdot 4$ & +++ \\
met ad - & 40 & $2 \cdot 2$ & +++ \\
met - gly & 0 & $2 \cdot 5$ & +++ \\
met - gly & 40 & $0 \cdot 8$ & +++ \\
— ad gly & 0 & $3 \cdot 7$ & +++ \\
- ad gly & 40 & $2 \cdot 3$ & +++ \\
met ad gly & 0 & $3 \cdot 9$ & +++ \\
met ad gly & 40 & $28 \cdot 8$ & $+/-$ \\
\end{tabular}

* All media also contained L-proline, L-histidine and L-tryptophan ( $50 \mathrm{mg} / \mathrm{L}$ of each) and glucose $2.8 \mathrm{~g} / \mathrm{L}$.

$\dagger$ See table I.

\section{Viability and morphology}

The unexposed culture of $E$. coli J62-2 (pUK1123) grew normally over a $24-\mathrm{h}$ period. However, after challenge with trimethoprim the viable count fell, but after $8 \mathrm{~h}$ this was reversed and after $24 \mathrm{~h}$ there was little difference between the viable counts of the challenged and unchallenged cultures (fig. 1). Microscopy of gram-stained smears showed that, as the viable count fell, cell elongation occurred (fig. 2). After $8 \mathrm{~h}$, as the viable count increased, the cells began to shorten. At $24 \mathrm{~h}$, the size and shape of the cells were indistinguishable from those of the unchallenged culture. This suggests that enzyme hyperproduction took place $c .8 \mathrm{~h}$ after exposure to trimethoprim.

\section{Effect of thymidine}

In sensitive $E$. coli strains, cell elongation in response to trimethoprim occurs in metabolic conditions similar to those of "thymineless death". Inhibition of the chromosomal dihydrofolate reductase results in the prevention of thymidine monophosphate synthesis and, therefore, DNA synthesis; however, it does not affect protein synthesis which is essential for death 
resulting from thymine starvation. ${ }^{14}$ To investigate whether thymineless conditions are required for the trimethoprim-induced synthesis of the type IV dihydrofolate reductase, production of the enzyme was investigated in the presence of thymidine.

A thymidine concentration of $2 \mathrm{mg} / \mathrm{L}$ was sufficient to allow bacteria to grow without inducing dihydrofolate reductase production (table III). Furthermore, bacteria cultured in IsoSensitest broth and challenged with trimethoprim in the presence of thymidine did not show a decrease in viable count (fig. 3 ) and microscopy revealed no cell elongation. These results suggest that thymine starvation may be an important trigger for the hyperproduction of the type IV dihydrofolate reductase. To investigate this, the production of the enzyme was examined in minimal medium. Earlier studies had demonstrated that the MIC of trimethoprim for E. coli J62-2 (pUK1123) was dependent on the presence of glycine, L-methionine and adenine, ${ }^{10}$ three compounds that are central to the thymidine pathway and to the action of trimethoprim. ${ }^{14}$

In minimal medium, enzyme hyperproduction occurred only when L-methionine, adenine and glycine were all present. When any of these compounds was absent, the bacteria were able to grow in the presence of trimethoprim $40 \mathrm{mg} / \mathrm{L}$ without producing high levels of dihydrofolate reductase (table IV). When all three were present, little growth occurred after $24 \mathrm{~h}$ although the bacteria produced high levels of dihydrofolate reductase. Microscopy revealed greatly elongated bacteria; but when the cultures were reincubated for a further $12 \mathrm{~h}$, growth occurred and the bacteria returned to normal size. Thus, when all three supplements were present (i.e., in conditions favouring "thymineless death") the situation mimicked what was happening over a longer time scale in complex medium.

As expected, in the presence of all three supplements, a thymidine concentration of $2 \mathrm{mg} / \mathrm{L}$ allowed growth in the absence of elevated levels of dihydrofolate reductase despite a trimethoprim concentration of $40 \mathrm{mg} / \mathrm{L}$.

Hyperproduction of the type IV dihydrofolate reductase occurred only under conditions promoting "thymineless death", which results from continued cell metabolism in the absence of a balanced synthesis of normal DNA. ${ }^{14,15}$ Morphologically, "thymineless death" is characterised by a marked increase in bacterial length and volume. ${ }^{16}$ Trimethoprim and other inhibitors of dihydrofolate reductase bring about "thymineless death" by disrupting the equilibrium between tetrahydrofolate and other tetrahydrofolate co-factor forms $;^{14,16}$ however, this has been observed previously only in trimethoprim-sensitive bacteria that do not possess plasmid-encoded dihydrofolate reductases. A thymineless state can also occur through depletion of tetrahydrofolate in the presence of pools of purines and amino acids adequate for growth. ${ }^{14,15}$

Clearly a given concentration of trimethoprim is not enough to cause hyperproduction of the type IV dihydrofolate reductase; rather, increased synthesis of the type IV enzyme seems to be an adaptation to conditions present during "thymineless death". Induction of enzymes as a response to "thymineless death" has been reported previously. ${ }^{17}$ We propose that once sufficient type IV enzyme has been produced, trimethoprim blockade can be overcome by the increased number of trimethoprim binding sites and the bacteria can resume growth. This mechanism of resistance whereby trimethoprim inhibition is overcome by production of large quantities of enzyme, rather than by synthesis of an inherently resistant dihydrofolate reductase, is similar to the chromosomal type of resistance. Indeed partial sequence analysis of the type IV dihydrofolate reductase reveals it to be closely related to the $E$. coli chromosomal enzyme. ${ }^{18}$

We thank the Wellcome Trust for grant no. 16376/1.5. We are very grateful to Professor M. V. Jesudason of the Microbiology Department at the Christian Medical College Hospital in Vellore, India for helping us obtain the original $E$. coli strain harbouring plasmid pUK 1123 .

\section{References}

1. Burchall JJ, Hitchings GH. Inhibitor binding analysis of dihydrofolate reductases from various species. $\mathrm{Mol}$ Pharmacol 1965; 1: 126-136.

2. Amyes SGB, Smith JT. R-factor trimethoprim resistance mechanism: an insusceptible target site. Biochem Biophys Res Commun 1974; 58: 412-418.

3. Huovinen P. Trimethoprim resistance. Antimicrob Agents Chemother 1987; 31: 1451-1456.

4. Amyes SGB, Towner KJ. Trimethoprim resistance; epidemiology and molecular aspects. $J$ Med Microbiol 1990; 31 : $1-19$.

5. Jansson C, Sköld O. Appearance of a new trimethoprim resistance gene, dhfrIX, in Escherichia coli from swine. Antimicrob Agents Chemother 1991; 35: 1891-1899.

6. Young H-K, Amyes SGB. A new mechanism of plasmid trimethoprim resistance: characterization of an inducible dihydrofolate reductase. J Biol Chem 1986; 261: 25032505.

7. Flensburg J, Sköld O. Massive overproduction of dihydrofolate

reductase in bacteria as a response to the use of trimethoprim. Eur J Biochem 1987; 162: 473-476.

8. Smith DR, Calvo JM. Nucleotide sequence of dihydrofolate reductase genes from trimethoprim-resistant mutants of Escherichia coli. Evidence that dihydrofolate reductase interacts with another essential gene product. Mol Gen Genet 1982; 187: 72-78

9. Tennhammar-Ekman B, Sundström L, Sköld O. New observations regarding evolution of trimethoprim resistance. $J$ Antimicrob Chemother 1986; 18 Suppl C: 67-76.

10. Young H-K, Jesudason MV, Koshi G, Amyes SGB. Unusual expression of new low-level-trimethoprim-resistance plasmids. J Clin Microbiol 1986; 24: 61-64.

11. Amyes SGB, Smith JT. Trimethoprim antagonists: effect of uridine in laboratory media. $J$ Antimicrob Chemother 1978; 4: $421-429$.

12. Davis BD, Mingioli ES. Mutants of Escherichia coli requiring methionine or vitamin $B_{12}$ J Bacteriol 1950; 60: 17-28.

13. Waddell WJ. A simple ultraviolet spectrophotometric method for the determination of protein. $J$ Lab Clin Med 1956; 48 : 311-314. 
14. Cohen SS, Barner HD. Studies on the induction of thymine deficiency and on the effects of thymine and thymidine analogues in Escherichia coli. J Bacteriol 1956; 71 : 588597.

15. Amyes SGB, Smith JT. Trimethoprim action and its analogy with thymine starvation. Antimicrob Agents Chemother $1974 ; 5: 169-178$

16. Hitchings GH. Functions of tetrahydrofolate and the role of dihydrofolate reductase in cellular metabolism. In: Hitchings GH (ed) Handbook of experimental pharma- cology. Inhibition of folate metabolism in chemotherapy. The origins and uses of co-trimoxazole. Chapter 64. Berlin, Springer-Verlag. 1983: 11-23.

17. Cohen SS, Barner H. Enzymatic adaption in a thymine requiring strain of Escherichia coli. J Bacteriol 1955; 69: 59-66.

18. Thomson CJ, Young H-K, Amyes SGB. N-terminal amino-acid sequence and subunit structure of the type IV trimethoprim-resistant plasmid-encoded dihydrofolate reductase. J Med Microbiol 1990; 32: 153-158. 